\title{
The effect of sowing date and plant density on the yield of maize (Zea mays L.) under different weather conditions
}

\author{
Ákos Tótin - Péter Pepó \\ University of Debrecen, Faculty of Agricultural and Food Sciences and Environmental Management, \\ Institute of Crop Science, Debrecen \\ totin.akos@gmail.com
}

SUMMARY

\begin{abstract}
Maize has high productivity and produces huge vegetative and generative phytomass, but this crop is very sensitive to agroecological (mainly to climatic, partly to pedological conditions) and agrotechnical circumstances. In Hungary, maize is grown on 1.1-1.2 million hectares, the national average yields vary between $4-7 t h a^{-1}$ depending on the year and the intensity of production technology. The longterm experiment was set up in 2015-2016 on chernozem soil in the Hajdúság (eastern Hungary). The maize research was set up on chernozem soil at the Látókép MÉK (Faculty of Agricultural and Food Sciences and Environmental Management) research area of the University of Debrecen. We examined the following commonly used hybrids of Hungary: SY ARIOSO (FAO 300), P9074 (FAO 310), P9486 (FAO 360), SY Octavius (FAO 400), GK Kenéz (FAO 410), DKC 4943 (FAO 410). The experiment was set up in three different plant densities. These were 60, 76, 90 thousand plant $h^{-1}$. The experiment was set up with three different sowing dates, early, average and late sowing. The yield was measured using a special plot harvester (Sampo Rosenlew 2010), measuring the weight of the harvested plot and also taking a sample from it. As a next step, we calculated the yield $\left(t \mathrm{~h}^{-1}\right)$ of each plot at $14 \%$ of moisture content to compare them to each other. We evaluated the obtained data using Microsoft Excel 2015.
\end{abstract}

Keywords: maize hybrid, sowing, plant density, yield

\section{INTRODUCTION}

As an effect of global warming, optimum sowing date of some arable plants what requiring high temperature can change in the future. Optimum sowing date is crucial from the aspect of adaptation to rapidly changing conditions in the case of maize yield, especially in dry years. With the decrease of fossil fuels, usage of maize as bioethanol is becoming an increasingly important topic. Therefore, the analysis of the nutritional parameters of maize is strongly reasonable and this factor is also affected by sowing date (Bene et al. 2014). Maize has high productivity, but it is very sensitive to the agroecological and agrotechnical conditions. The sowing of maize is the most important work process of the successful growing season. The mistakes in sowing can't be eliminated during further work processes in the growing season. Therefore, great care is needed (Füzy 2005). In Hungary, maize is grown on 1.1-1.2 million hectares, the national average yield varies between 4 and $7 \mathrm{tha}$ ${ }^{1}$ depending on the year and the intensity of production technology (Pepó et al. 2006). The impacts of weather factors (Huzsvai and Nagy 2005, Pepó et al. 2005), and global climate change on maize yields are of special importance (Várallyay 2007). The effect of agrotechnical elements is exerted in a complex way in the soil-plant system (Németh 2006). The effects of nutrient supply (Kovačević et al. 2006, Izsáki 2007), plant density (Berzsenyi and Lap 2006) and irrigation (Ruzsányi 1992, Berényi et al. 2007) on the yield stability of maize are especially important. These agrotechnical factors exert their effect via interactions and not independently (Pepó et al. 2007). According to (Menyhért 1985, Sárvári 2001) early sowing recommends. Based on (Pepó 2012) the maize is specific productive plant, essential to determine the optimum density because, the corn plant to produce $1 \mathrm{~kg}$ of dry material used for 300 liters of water. 8 tons of yield are (if the grain the $50 \%$ of the total organic material) amount of water used throughout the growing period is $480 \mathrm{~mm}$, which is part of the precipitation fell in vegetation, the missing part of the water stored in the soil cover of the plant. Therefore, it is important to determine the plant density (Szabó 2012).

\section{MATERIAL AND METHODS}

The long-term experiment was set up in 2015-20162017 on chernozem soil in the Hajdúság (eastern Hungary). Regarding the physical characteristics of the soil, the area can be classified as loam and has a nearly neutral $\mathrm{pH}$ value $\left(\mathrm{pH}_{\mathrm{KCl}}=6.46\right)$. It has a medium-level humus content $(2.8 \%)$ and a humus depth of about $80 \mathrm{~cm}$. Its supply of phosphorous is medium and its supply of potassium can be considered good. Water supplies of the soil are favorable. Examined hybrids were DKC4943, GK Kenéz, P9074, P9486, SY Arioso, SY Octavius. The experiment was set in 60-75-90 thousand plants ha ${ }^{-1}$ plant density. We use three sowing date. Early sowing date: beginning of April, Average: middle of April, Late sowing: beginning of May. These were set up in four replications. The results were presented in the average of the replications. The fore crop was winter wheat. The experiment was set in one nutrient level. The fertilizer was dispensed in spring. The amount of $\mathrm{N}$ was $108 \mathrm{~kg} \mathrm{ha}^{-1}$. We harvest the plot with a SAMPO plot harvester. The meteorological factors are shown in Table 1.

For the statistical evaluation of the experiment we used SPSS 13.0 for Windows and Microsoft Excel 
2010 software. Pearson bifactorial analysis of correlation analysis was used.

In the correlation analysis, we determined the following types of correlations according to the $r$ values: $\mathrm{r}<0.4$ : loose, 0.4-0.7: medium, 0.7-0.9: tight, $>0.9$ : strong.

The amount of meteorological parameters in the examined crop years (Látókép, 2015-2017)

\begin{tabular}{|c|c|c|c|c|c|c|c|c|c|}
\hline & Months & April & May & June & July & August & September & October & Total/Average \\
\hline \multirow{4}{*}{$\begin{array}{l}\text { Precipitation } \\
(\mathrm{mm})\end{array}$} & 30 year's average & 42.4 & 58.8 & 79.5 & 65.7 & 60.7 & 38.0 & 31.8 & 376.9 \\
\hline & 2015 & 21.9 & 52.9 & 60.5 & 35.6 & 84.0 & 48.9 & 86.6 & 390.4 \\
\hline & 2016 & 144 & 692 & 1463 & 846 & 717 & 634 & 526 & 5022 \\
\hline & 2017 & 504 & 319 & 623 & 716 & 475 & 684 & 404 & 3725 \\
\hline \multirow{4}{*}{$\begin{array}{l}\text { Temperature } \\
\left({ }^{\circ} \mathrm{C}\right)\end{array}$} & 30 year's average & 10.7 & 15.8 & 18.8 & 20.3 & 19.6 & 15.8 & 10.3 & 15.9 \\
\hline & 2015 & 10.1 & 15.8 & 19.9 & 22.9 & 23.3 & 17.8 & 11.2 & 17.3 \\
\hline & 2016 & 125 & 157 & 201 & 229 & 198 & 172 & 152 & 175 \\
\hline & 2017 & 101 & 163 & 209 & 21 & 221 & 17 & 111 & 169 \\
\hline
\end{tabular}

\section{RESULTS AND DISSCUSION}

In the 2015-2016 crop year we examined 6 hybrid with different genetically background. The SY Arioso (FAO 300), P9074 (FAO 310), P9486 (FAO 360), SY Octavius (FAO 400), GK Kenéz (FAO 410), DKC 4943 (FAO 410). The chart depicted on the average of hybrids.

On the Figure 1 we can see that in 2015 the early sowing date produced the highest amount of yield. In average it was $12.7 \mathrm{t} \mathrm{ha}^{-1}$. The second best was the average sowing with $12.6 \mathrm{t} \mathrm{ha}^{-1}$. In 2016 the highest amount of yield was produced by the plants form the average sowing date $12.2 \mathrm{tha}^{-1}$. It followed by the late sowing date $12.1 \mathrm{t} \mathrm{ha}^{-1}$. In 2017 the average and late sowing produced the same amount of yield in average14.2 $\mathrm{t} \mathrm{ha}^{-1}$. And the early sowing produced only a little less $14.1 \mathrm{t} \mathrm{ha}^{-1}$.

Figure 1: The amount of maize yield in the field experiment (Látókép, 2015-2017)

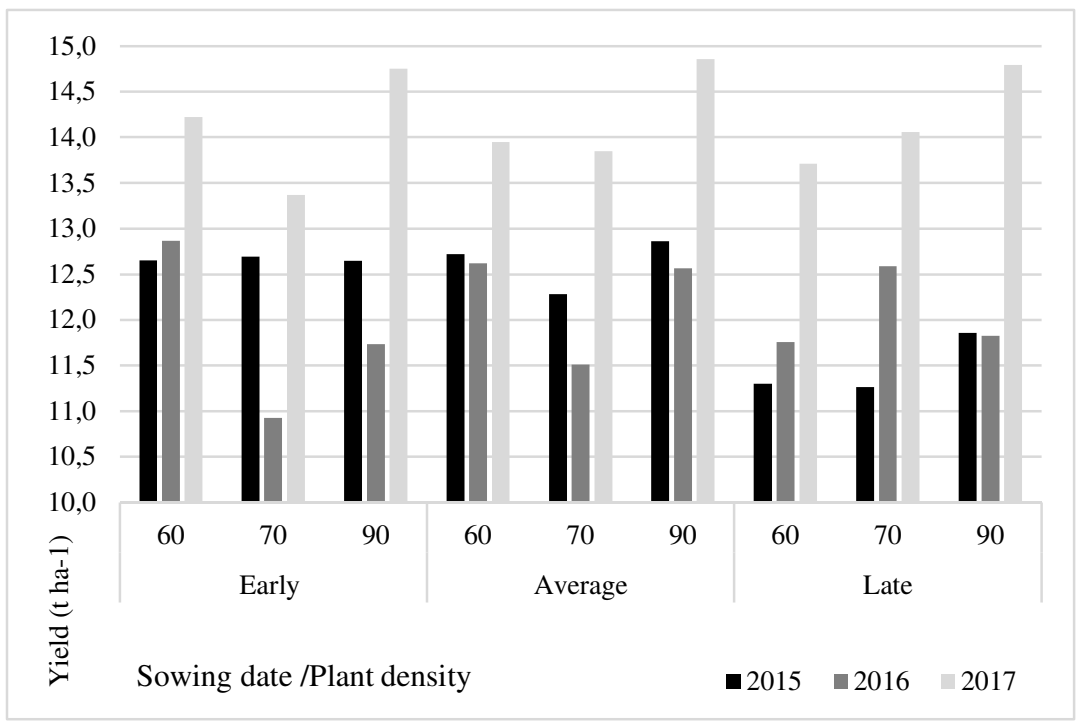

On the Table 2 we can see the amount of yield in each year in the average of the replications. In each year the parcels were harvested by a special harvester. Than we measured the moisture content of the plots and calculated the yield in $\mathrm{t} \mathrm{ha}^{-1}$. The yield was calculated an equal moisture content which was $14 \%$.

The Table 3 shows the correlation between the effect of the annual weather, sowing, hybrid, density and yield. There is no correlation between each element but between the year and the yield there is medium strong positive correlation.
On the Table 4 we can see that in 2015 the statistical analysis found a negative, moderately strong correlation between the sowing date and the yield.

On the Table 5 we can see that in 2016 the statistical analysis does not found any correlation between the elements.

On the Table 6 we can see that in 2017 the statistical analysis does not found any correlation between the elements. 
Effects of sowing date and plant density on maize yield (Látókép, 2015-2017)

\begin{tabular}{|c|c|c|c|c|c|c|c|}
\hline $\begin{array}{c}\text { Sowing } \\
\text { date }\end{array}$ & $\begin{array}{c}\text { Plant } \\
\text { density }\end{array}$ & 2015 & 2016 & 2017 & 2015 & 2016 & 2017 \\
\hline & & \multicolumn{3}{|c|}{ SY Arioso } & \multicolumn{3}{|c|}{ SY Octavius } \\
\hline \multirow{3}{*}{$\begin{array}{l}\text { Early } \\
\text { sowing }\end{array}$} & 60 & 12.4 & 11.8 & 11.6 & 12.6 & 13.0 & 15.7 \\
\hline & 76 & 13.4 & 10.8 & 11.3 & 11.4 & 10.3 & 13.6 \\
\hline & 90 & 12.0 & 10.6 & 13.6 & 12.6 & 11.9 & 14.1 \\
\hline \multirow{3}{*}{$\begin{array}{l}\text { Average } \\
\text { sowing }\end{array}$} & 60 & 11.8 & 12.0 & 15,2 & 13.4 & 13.9 & 14.0 \\
\hline & 76 & 13.1 & 11.0 & 13.5 & 11.0 & 10.9 & 13.8 \\
\hline & 90 & 12.8 & 11.9 & 13.9 & 12.6 & 12.5 & 15.2 \\
\hline \multirow{4}{*}{$\begin{array}{l}\text { Late } \\
\text { sowing }\end{array}$} & 60 & 10.4 & 12.1 & 15.2 & 12.2 & 13.6 & 14.3 \\
\hline & 76 & 12.8 & 11.6 & 14.1 & 9.9 & 11.8 & 12.6 \\
\hline & 90 & 12.4 & 11.8 & 14.0 & 11.4 & 13.4 & 14.9 \\
\hline & & \multicolumn{3}{|c|}{ P9074 } & \multicolumn{3}{|c|}{ Kenéz } \\
\hline \multirow{3}{*}{$\begin{array}{l}\text { Early } \\
\text { sowing }\end{array}$} & 60 & 12.9 & 12.7 & 12.6 & 12.2 & 13.2 & 15.3 \\
\hline & 76 & 11.2 & 10.0 & 12.0 & 14.8 & 11.9 & 15.6 \\
\hline & 90 & 12.5 & 11.1 & 14.0 & 13.1 & 12.3 & 15.0 \\
\hline \multirow{3}{*}{$\begin{array}{l}\text { Average } \\
\text { sowing }\end{array}$} & 60 & 13.7 & 13.7 & 13.6 & 11.5 & 12.1 & 12.1 \\
\hline & 76 & 12.2 & 10.5 & 13.0 & 12.7 & 13.2 & 15.0 \\
\hline & 90 & 12.7 & 11.2 & 13.5 & 12.0 & 12.4 & 14.2 \\
\hline \multirow{4}{*}{$\begin{array}{l}\text { Late } \\
\text { sowing }\end{array}$} & 60 & 13.1 & 13.3 & 14.0 & 9.9 & 9.5 & 13.5 \\
\hline & 76 & 11.4 & 10.8 & 13.0 & 12.4 & 14.6 & 14.1 \\
\hline & 90 & 12.4 & 11.9 & 14.4 & 11.3 & 12.5 & 15.3 \\
\hline & & \multicolumn{3}{|c|}{ P9486 } & \multicolumn{3}{|c|}{ DKC 4943} \\
\hline \multirow{3}{*}{$\begin{array}{l}\text { Early } \\
\text { sowing }\end{array}$} & 60 & 12.0 & 12.6 & 15.7 & 13.8 & 13.9 & 14.5 \\
\hline & 76 & 13.6 & 12.2 & 14.9 & 11.8 & 10.3 & 12.8 \\
\hline & 90 & 11.8 & 12.0 & 15.2 & 13.9 & 12.5 & 16.6 \\
\hline \multirow{3}{*}{$\begin{array}{l}\text { Average } \\
\text { sowing }\end{array}$} & 60 & 12.7 & 11.2 & 16.0 & 13.2 & 12.7 & 12.8 \\
\hline & 76 & 13.8 & 12.7 & 14.0 & 10.8 & 10.9 & 13.7 \\
\hline & 90 & 13.2 & 12.4 & 15.4 & 14.0 & 15.0 & 16.9 \\
\hline \multirow{3}{*}{$\begin{array}{l}\text { Late } \\
\text { sowing }\end{array}$} & 60 & 9.2 & 11.4 & 12.8 & 13.0 & 10.6 & 12.4 \\
\hline & 76 & 11.3 & 13.1 & 14.0 & 9.8 & 13.6 & 16.5 \\
\hline & 90 & 10.7 & 12.6 & 14.2 & 12.9 & 8.8 & 15.9 \\
\hline
\end{tabular}

Table 3

The Pearson Correlation between the year, sowing date, hybrid, plant density and yield (Látókép, 2015-2016-2017)

\begin{tabular}{lccccc}
\hline $\begin{array}{c}\text { Correlations } \\
\text { 2015-2016-2017 }\end{array}$ & Year & Sowing & Hybrid & Density & Yield \\
\hline Year & 1 & 0 & 0 & 0 & $0.503(* *)$ \\
Sowing & 0 & 1 & 0 & 0 & -0.08 \\
Hybrid & 0 & 0 & 1 & 0 & 0.141 \\
Density & 0 & 0 & 0 & 1 & 0,062 \\
Yield & $0.503(* *)$ & -0.08 & 0.141 & 0.062 & 1 \\
\hline
\end{tabular}

Note: $* *$ correlation is significant at the 0.01 level (2-tailed).

Table 4

The Pearson Correlation between the sowing date, hybrid, plant density and yield in 2015 (Látókép)

\begin{tabular}{lcccc}
\hline $\begin{array}{c}\text { Correlations } \\
2015\end{array}$ & Sowing & Hybrid & Density & Yield \\
\hline Sowing & 1 & 0 & 0 & $-0.419(* *)$ \\
Hybrid & 0 & 1 & 0 & 0.013 \\
Density & 0 & 0 & 1 & 0.084 \\
Yield & $-0.419(* *)$ & 0.013 & 0.084 & 1 \\
\hline
\end{tabular}

Note: $* *$ correlation is significant at the 0.01 level (2-tailed).
The Pearson Correlation between the sowing date, hybrid, plant density and yield in 2016 (Látókép)

\begin{tabular}{lcccc}
\hline $\begin{array}{c}\text { Correlations } \\
2016\end{array}$ & Sowing & Hybrid & Density & Yield \\
\hline Sowing & 1 & 0 & 0 & 0.071 \\
Hybrid & 0 & 1 & 0 & 0.191 \\
Density & 0 & 0 & 1 & -0.118 \\
Yield & 0.071 & 0.191 & -0.118 & 1 \\
\hline
\end{tabular}

Table 6

The Pearson Correlation between the sowing date, hybrid, plant density and yield in 2017 (Látókép)

\begin{tabular}{lcccc}
\hline $\begin{array}{c}\text { Correlations } \\
2017\end{array}$ & Sowing & Hybrid & Density & Yield \\
\hline Sowing & 1 & 0 & 0 & 0.02 \\
Hybrid & 0 & 1 & 0 & $0.320(*)$ \\
Density & 0 & 0 & 1 & $0.270(*)$ \\
Yield & 0.02 & $0.320(*)$ & $0.270(*)$ & 1 \\
\hline Note: $* *$ correlation is significant at the 0.05 level $(2-$ tailed $)$.
\end{tabular}

Note: $* *$ correlation is significant at the 0.05 level (2-tailed)

\section{CONCLUSIONS}

The long-term experiment was set up at at Látókép research area of the University of Debrecen on chernozem soil. We use six top hybrid of Hungary. 2015 the early sowing date produced the highest amount of yield. Than the average sowing and the less yield was produced in the late sowing. In 2016 the weather was much hotter than in the other 2 year. In this year the average sowing produce the biggest yield because at the early sowing there was less precipitation. And in the second half of the crop year it rained much more. Therefore the late sowing was the second best in this year. In 2017 the weather was close to the 30 year's average therefore this year produced the highest amount of yield. In 2017 the distribution of precipitation was more even than in previous years. The temperature was high but it was not as high a day as in the previous years. In this year the three sowing dates yield were close to each other because every plant from each sowing date get enough precipitation and heat to grow fast. The statistical analysis found correlation between the sowing date and the yield in 2015. The correlation was negative moderately strong so if we late with the sowing we can lose yield.

In 2015 the best hybrid was the GK Kenéz in the early sowing date with 14.8 tha $^{-1}$ at the 76 thousand plant ha ${ }^{-1}$ plant density. The second best hybrid was the DKC 4943. It produced their best in the average sowing date $14 \mathrm{t} \mathrm{ha}^{-1}$ in the 90 thousand plant ha plant density and the third best yield in the early sowing with $13.9 \mathrm{t} \mathrm{ha}^{-1}$ in the 90 thousand plant ha ${ }^{-1}$ plant density. In this year the third best hybrid was the P9486. It produced the best yield in the average sowing date in the "average" plant density 76 thousand plant ha ${ }^{-1}$ plant density. It was $13.8 \mathrm{t} \mathrm{ha}^{-1}$.

In 2016 the best hybrid was the DKC4943 in the average sowing date with $15 \mathrm{t} \mathrm{ha}^{-1}$ at the 90 thousand plant $\mathrm{ha}^{-1}$ plant density. The second best hybrid was 
the GK Kenéz. It produced their best in the late sowing date $14.6 \mathrm{t} \mathrm{ha}^{-1}$ in the 76 thousand plant ha plant density. In this year the third best hybrid was the SY Octavius. It produced the best yield in the average sowing date at the 76 thousand plant $\mathrm{ha}^{-1}$ plant density. It was $13.9 \mathrm{t} \mathrm{ha}^{-1}$.

In 2017 the best hybrid was the DKC4943 in all the three sowing date it produced with $16.6 \mathrm{t} \mathrm{ha}^{-1}$ at the 90 thousand plant ha $^{-1}$ plant density in the early sowing date, $16.9 \mathrm{t} \mathrm{ha}^{-1}$ at the 90 thousand plant haplant density in the average sowing date and $16.5 \mathrm{tha}^{-1}$ at the 76 thousand plant $\mathrm{ha}^{-1}$ plant density in the late sowing date. The second best hybrid was the P9486. It produced their best in the average sowing date $16 \mathrm{tha}$ ${ }^{1}$ in the 60 thousand plant $\mathrm{ha}^{-1}$ plant density. In this year the third best hybrid was the SY Octavius. It produced their best yield in the early sowing date at the 60 thousand plant $\mathrm{ha}^{-1}$ plant density which was $15.7 \mathrm{t} \mathrm{ha}^{-1}$
The early sowing date in the future will have a great role. Because the global warming change the sowing date of some plants. With using earlier sowing, result greater crop safety, because plants can avoid atmospheric drought during the summer. Both in dry and rainy crop year the early sowing produce close the same amount of yield than the average sowing. Most of the cases the average sowing date has the highest amount of yield. The late sowing was the second and the early sowing produced the less yield.

\section{ACKNOWLEDGMENTS}

The work/publication is supported by the EFOP3.6.3-VEKOP-16-2017-00008 project. The project is co-financed by the European Union and the European Social Fund.

\section{REFERENCES}

Bene, E.-Sárvári, M.-Futó, Z. (2014): The effect of sowing date on three maize hybrids with different growing seasons on their quantity and some of their quality parameters. Növénytermelés. 63. 4: 5-24.

Berényi, S.-Vad, A.-Pepó, P. (2007): Effects of fertilization and cropyears on maize (Zea mays L.) yields in different crop rotations. Cereal Res. Commun. 35. 2: 241-244.

Berzsenyi Z.-Lap D. Q. (2006): A növényszám hatásának vizsgálata különbözı tenyészidejü kukorica (Zea mays L.) hibridek vegetatív és reproduktív szerveinek növekedésére Richards-függvénnyel. Növénytermelés. 55. 3-4: 17-23.

Füzy, J. (2005): Maize sowing in practice. Agrofórum Extra. 59: 9.

Huzsvai, L.-Nagy, J. (2005): Effect of weather on maize yields and the efficiency of fertilization. Acta Agronomica Hungarica. 53. 1: 31-39.

Izsáki, Z. (2007): N and P impact on the yield of maize in a longterm trial. Cereal Res. Commun. 35. 4: 1701-1711.

Kovačević, V.-Rastija, M.-Rastija, D.-Josipović, M.-Šeput, M. (2006): Response of Maize to Fertilization with $\mathrm{KCl}$ on Gleysol of Sava Valley Area. Cereal Res. Commun. 34. 2-3: 11-29.

Menyhért, Z. (1985): Maize production handbook. Mezőgazdasági Kiadó. Budapest. 273-278.

Németh, T. (2006): Nitrogen in the soil-plant system, nitrogen balances. Cereal Res. Commun. 34. 1: 61-65.
Pepó P.-Vad A.-Berényi S. (2005): Agrotechnikai tényezők hatása a kukorica termésére monokultúrás termesztésben. Növénytermelés. 54. 4: 317-326.

Pepó, P.-Vad, A.-Berényi, S. (2006): Effect of some agrotechnical elements on the yield of maize on chernozem soil. Cereal Res. Commun. 34. 1: 621-624.

Pepó, P.-Zsombik, L.-Vad, A.-Berényi, S.-Dóka, L. (2007): Agroecological and management factors with impact on the yield and yield stability of maize (Zea mays L.) in different crop rotation. Analele Universitatii Oradea. Facultatea de Protectia Mediului. 13: 181-187.

Pepó, P. (2012): Reserves in maize production agrotechnics. Agrofórum Extra. 47: 5-11.

Ruzsányi L. (1992): A főbb növénytermesztési tényezők és a vízellátás kölcsönhatásai. Akadémiai doktori értekezés tézisei. Debrecen.

Sárvári, M.-Futó, Z. (2001): The effect of sowing date in different genotype of maize hybrids yield. Crop production. 50. 1: 4360 .

Szabó, Sz. (2012): The drought of maize and its physiological reactions. Agronapló. 12: 18.

Várallyay Gy. [Láng I.-Csete L.-Jolánkai M. (szerk.)] (2007): A globális klímaváltozás: hazai hatások és válaszok (A VAHAVA Jelentés). Agrokémia és Talajtan. 56. 1: 199-202. 